\title{
The "Internet+" Era'S Revelation of the Reform of Professional English Teaching in Higher Vocational Colleges
}

\section{Li Linna}

\author{
Business English Department, Harbin Financial College
}

\section{Key Words: Internet+; Business English; Teaching Reform}

\begin{abstract}
The "Internet+" is a new form of Internet evolution that goes deep into all areas of society. Under the background of "Internet+", the trend of business English teaching in the era of adapting to the times is also an inevitable choice. Business English teaching staff should be actively thinking about the new development direction of business English teaching, under the circumstances of "Internet +", business English major graduates can gain how to adapt to the pace of economic development of professional skills and how to effectively serve local regional economies. This paper mainly discusses the main problems of the current business English teaching, and under the request of the era of "Internet + Education", how teachers cultivate business English major students' vocational skills can make them stay ahead in the workplace.
\end{abstract}

\section{Introduction}

In short, "Internet+" is a new model of economic growth. "Internet + " is the depth fusion of the Internet and traditional industry that gives full play to the optimized integration of the Internet in the various factors of production to enhance the real economy of innovation and creative new ecological productivity. Mr. Ma Huateng argues that "Internet +" should rise to a national level.

"Internet+" is a completely different concept than "+ Internet". It is not easy to think that all walks of life are "Internet+" as long as they are connected to the Internet. The symbol "+" in "Internet+" means creative. Innovation is the soul of the "Internet +", to learn to use the "Internet dimension" to think and solve problems. In addition, the "transboundary integration”, "respect for humanity" and "connecting everything" are the salient features of the "Internet +". "Crossing the boundary" is to change, to be open, and that is the foundation of innovation. "Respecting human nature", for the education workers, is to focus on the creativity of the students. "Connectivity" is different, but "connecting everything" is an internal requirement and goal of "Internet +".

In the "Internet +" era, education was also a plus, so there was "Internet + Education". The education elements of traditional education are schools, teachers and classrooms. In the "Internet + education" environment, you can choose from any network, terminal, or any superior teaching resource. This is the charm of "Internet + Education". No matter which education level you belong to, you can get the best teachers at home. The advent of the era of "Internet + education" makes the teaching and learning activities done via the Internet. Interaction between teachers and students will no longer restricted by time and space. In class, the feedback from the teaching and the course of the class meets the perfect match through the Internet. However, this does not mean that the "Internet + education" can completely replace the traditional education. Industry pundits agree that the former will only bring new vitality to the latter. Li Jingwen, a member of the Chinese academy of engineering, said that China's education is moving towards a 4.0. 


\section{Business English Teaching in Higher Vocational Colleges}

The aim of the education talents training in higher vocational colleges is mainly to serve the local regional economy. It is closely related to local economic development in terms of application, practice and occupation. However, the fact is that many vocational college English majors are still carried out in the traditional teaching mode. Teacher's responsible for teaching, while the students are responsible for listening. Students mechanically memorize, and the theories break away from practice. Business English curriculum is not based on market demand and setting, but completely made by the ministry of education of college English - a compulsory course with English professional skills (listening, speaking, reading, writing and translating), business knowledge and English writing course and a few of the combination of the training courses. The course that students learn is the simple addition of "basic English skills + business knowledge skills", which breaks the internal relationship of market demand. Under such a rigid talent training scheme, students learning objective is not clear. Learning enthusiasm is not high, thus cause the workplace after graduation competitiveness is not enough. The status of the employment rate is low.

\section{Theory is good, practice is short.}

Most vocational business English majors are taught by theoretical knowledge and then practice exercises with a certain amount of time. Students may think theories are enigmatic and formidable when they learn, because of a lack of practical exercises. They think learning is very boring. They doubt themselves no talent in this field, even thought they chose the wrong major. The reality is that the role of teachers is also not optimistic. Because most of the higher vocational teachers are English majors, and the English teachers with higher education level are majoring in English and American literature or linguistics, teachers themselves are lack of practical work experience related to the business. Being an armchair strategist lets a person feel humbled. Students will feel it is difficult to understand those theories. The teaching situation of business English is in the awkward situation. The students either can not ask the question, or the problems teacher asks are unable to answer. Because of the same lack of practical experience, the problems beyond the textbook are that many teachers struggle to answer. The lack of theoretical knowledge directly affects the actual operation of the students. In the end, many employers have had to train their graduates before using them, causing the waste of people, money and things of the company.

Traditional business English courses are based on "basic English skills + business knowledge skills". But the reality is that in the age of the Internet plus, traditional forms of trade are changing rapidly. In e-commerce, for example, from the well-known b2b, b2c, c2c mode developing to some innovation model, such as agents, businesses and consumers (ABC), online to offline (o2o), business to family (b2f), providers to the demand side (p2d), and so on. The development and application of emerging technologies is not synchronized to classroom teaching. Students are in a critical stage for the acquisition of knowledge, but unheard of to the forefront of subject knowledge. This is a problem that each education workers should think over.

\section{The "Internet +" as a Revelation to Higher Vocational Business English Teaching}

First, the traditional business English teaching mode is mainly taught by teaching materials, so the teaching material is one of the important guarantees to finish the business English teaching. However, it is not easy for textbooks to be updated. Because, today's society has marched into an expressway in which knowledge and technology are developing rapidly. As the teaching materials published cycle is relatively long, the transmission of information only by the publication of the 
teaching material is difficult to obtain. That is why the age of the Internet plus has broken this awkward situation. Through the Internet, students can study microcourses and mooc online. Through open access channels, students can access cutting-edge technology information, which is helpful for understanding the development prospects of the subject and the major. Through the university's library's database electronic reading, you can obtain more knowledge that you want to know and not learn in the textbook. It is fair to say that in the era of "Internet + ", there is hope for the best global education resources. However, we can't deny the guidance of the physical teachers, and we can't ignore the course material. Classroom teaching is the students "staple”, while App software and network classroom learning belong to the category of "side dish" for students. They are supplementary to the knowledge acquisition, must not catch one and lose another.

Second, the teacher as the master of classroom teaching activities determines which knowledge the students will acquire and how much advanced knowledge will be obtained. As the lead, therefore, teachers should be actively involved in the daily teaching "Internet +" spirit. Teachers can use some advanced information and communication technologies, such as "barrage" technology, real-time understanding the real thoughts of students for the course, to adjust teaching strategies, achieve good teaching effect and reflect the idea that students are fundamental. Positive thinking creates new. The classroom teaching mode that the student is willing to accept, the combination of the network teaching platform in the class, stimulate the students' study interest fully. On network teaching platform, teachers can simulate the business situation, setting up practice platform, to confirm whether the students studying the theory of knowledge in the classroom can be used to guide practice, so as to exercise the students' professional skills, to improve class teaching quality and teaching effect.

Third, teachers can introduce “Internet +" to students' evaluation mechanism. The teachers' evaluation of the students' courses can be considered in terms of the traditional test questions and the operation condition of the network teaching platform. Test question and answer can test students' mastering of theoretical knowledge and practical work situation of the network platform operation, which can test whether students can apply theory knowledge. This kind of "theory + practice" double check can inspire students to abandon the bad learning habits: reading in a pedantic way, can improve the students ability to solve practical problems. Through double check system, the students can, according to their own performance in the course of the assessment, deepen understanding of the problem, through various means to make up for the lack of the related knowledge. In this way, the students who develop business English majors are likely to adapt to the future career.

\section{Conclusion}

The Internet +education" is the current direction of education reform. How to grasp the pulse of The Times and combine the content of the course with the standard of professional qualifications? How to develop professional and competitive business English talent? How to build a new business English teaching model? How to cultivate the innovative ability of business English students? In the age of "Internet +", these are questions that should be explored by every business English teacher.

\section{Reference}

[1] Cheng Yanxia. Based on the Training of Students' Independent Learning Ability[J]. Journal of Correspondence University of Hubei, 2015(16):149-150.

[2]Li Hua, Xie Zhixin, Xu Zhenzhen. Based on the Idea of “Internet+” University Student 
Innovation Startup Education[J]. Shandong Agricultural University Newspaper, 2015(3):37-39.

[3]Qiu Min. Discuss the Professional Abilities of Business English Majors[J]. Science and Technology Information, 2012(35):336-337. 